\title{
Evaluation of beetroot (Beta vulgaris L.) leaves during its developmental stages: a chemical composition study
}

Polyana Batoqui França BIONDO ${ }^{1}$, Joana Schuelter BOEING ${ }^{1}$, Érica Oliveira BARIZÃO' ${ }^{1}$, Nilson Evelazio de SOUZA ${ }^{2}$, Makoto MATSUSHITA ${ }^{1}$, Claudio Celestino de OLIVEIRA ${ }^{1}$, Marcela BOROSKI ${ }^{1,3}$, Jesuí Vergílio VISENTAINER ${ }^{1 *}$

\begin{abstract}
Beetroot leaves (Beta vulgaris L.) are commonly cut off and discarded before using its bulb due to lack of knowledge of how to use them. Aiming at using these leaves, in the present study, in natura and dehydrated beetroot leaves were chemically characterized in terms of fatty acid composition, proximate composition, minerals, total phenolic compounds (TPC), and antioxidant activity by DPPH ${ }^{\circ}$ in different stages $(60,80$, and 100 days) of development. The beetroot leaves showed significant levels of protein and lipids in all developmental stages, and all proximate composition nutrients decreased during these maturation stages; the highest content was observed at 60 days. The Fe content decreased during the developmental stages (from 342.75 to $246.30 \mathrm{mg} \cdot \mathrm{kg}^{-1}$ ), while the content of $\mathrm{K}$ increased (from 13,367.64 to 20,784.90 mg. $\mathrm{kg}^{-1}$ ). With regard to to fatty acid composition, linolenic acid was present in the greatest quantity, and it increase up to $2.58 \mathrm{mg} \cdot \mathrm{g}^{-1}$ (in natura) and $40.11 \mathrm{mg} . \mathrm{g}^{-1}$ (dehydrated) at 100 days of development. The $n-6 / n-3$ ratios were low in all stages. The TPC and antioxidant activity by DPPH' changed during the developmental stages. The TPC was highest in the 100-day dehydrated leaves $\left(15.27 \pm 0.12 \mathrm{mg} \mathrm{GAE}^{-1}\right.$ $\mathrm{FW}$ ), and the $50 \%$ inhibition of DPPH $\left(\mathrm{IC}_{50} 89.52 \mu \mathrm{g} \cdot \mathrm{mL}^{-1}\right.$ ) were better in the 60 -day in natura leaves. This study shows that all developmental stages produced satisfactory results, and therefore, these leaves can be reused as food. The antioxidant activity and the chemical constituents, mainly the $\omega$-3fatty acid, increased during the stages of development.
\end{abstract}

Keywords: beetroot leaves, minerals, fatty acid, alpha-linolenic acid, antioxidant activity.

\section{Introduction}

Epidemiological studies have demonstrated the protective effect of fruit and vegetable intake against chronic and degenerative diseases such as cancer (Padilha \& Pinheiro, 2004; Kabat et al., 2010). Brazil is a major producer of fruit and vegetables, which are widely consumed, and of other less used food sources. Recent studies have investigated the composition profiles of underutilized foods and their co-products in attempt to investigate their potential as functional foods (Pereira et al., 2003; Almeida et al., 2009; Boroski et al., 2011).

Beetroot (Beta Vulgaris L.) belongs to the Chenopodiaceae family and is originally from temperate climate regions of Europe and North Africa. In Brazil, it is grown in the South and Southeast regions (77\% of the total produce), and the annual yield is 30-40 tons per hectare, which corresponds to an average production of 280 tons. In street markets, indoor markets, and fruit and vegetable distribution centers, their leaves are cut off from the bulb to be used as organic fertilizer and animal feed or are discarded into the environment as waste (Amaral et al., 2004; Mello et al., 2008). Beetroot leaves are underused due to lack of proper knowledge, specially of their nutritive value and how to cook them and also because of dietary habits (Vilhena \& Silva, 2007).
Among vegetable leaf constituents, fatty acids stand out, especially polyunsaturated fatty acids of the omega- 3 series such as alpha-linolenic acid, because they play an important role as structural membrane lipids, particularly in nerve tissue and the retina, and are precursors of eicosanoids (Institute of Medicine of the National Academies, 2002). The consumption of these fatty acids can prevent diseases such as rheumatoid arthritis, coronary diseases, colon, prostate, and brain cancer, and other diseases common in western societies (Connor, 2010). Alternative and complementary sources of omega- 3 are necessary to change the dietary ratio of omega- 6 and omega- 3 (n-6/n-3), especially in western countries, where this ratio has remained as 1:1 for many generations. However, in the last years, this ratio has changed and reached 17:1, with major consequences for public health (Simopoulos, 2002).

Antioxidants are compounds that inhibit or slow down the oxidation of lipids and other molecules through the neutralization of free radicals (Zheng \& Wang, 2001). Among the antioxidants present in in natura vegetable leaves, phenolic compounds are found in great amounts, as well as in vegetables, fruit and medicinal plants (Abdel-Hameed, 2009). Phenolic compounds, which result from the secondary metabolism of plants and are formed in stress conditions (infections, UV rays, and others), stand out for their wide distribution in nature and

\footnotetext{
Received 04 Oct., 2013

Accepted 10 Jan., 2014 (006206)

1 Department of Chemistry, State University of Maringá - UEM, Maringá,PR, Brazil, e-mail: jvvisentainer@uem.br

${ }^{2}$ Universidade Tecnológica Federal do Paraná - UTFPR, Campus Londrina, Tecnologia de Alimentos, Londrina, PR, Brazil

${ }^{3}$ Federal University of Latin American Integration - UNILA, Foz do Iguaçú, PR, Brazil

${ }^{*}$ Corresponding author
} 
their antioxidant activity (Arbos et al., 2010). They are important because they can retard the development of coronary and cardiovascular diseases, cancer, and intestinal inflammatory diseases (Chun et al., 2005; Pawlowska et al., 2006).

Mineral elements are essential in human diet due to their various bodily functions, such as the macro minerals $\mathrm{Ca}$ and $\mathrm{Mg}$ in the formation of bones, teeth, and tissues. Fe is a component of the hemoglobin molecule, which is essential for the transport of oxygen and cell breathing. These elements are found in cereals, fruit, and in roots and leaves of vegetables (Ekholm et al., 2007; Kawashima \& Soares, 2003).

Some scientific studies on foods have reported changes in chemical composition at different stages of development of fruits, vegetables, and leaves (Bulbovas et al., 2005; Telci et al., 2009; Oliveira et al., 2011; Celi et al., 2011; Leite et al., 2011; Peiretti et al., 2013). However, there are no studies that address the different stages of development of beetroot leaves; therefore, the goal of the present study was to investigate the proximate composition, the mineral and fatty acid contents, and the antioxidant activity of in natura and dehydrated beetroot leaves at different stages of development $(60,80$, and 100 days) in order to investigate the use of their leaves as food. Today, in literature there are studies available on the reuse of cassava (Silva et al., 2012; Carvalho et al., 2002) and carrot leaves (Pereira et al., 2003; Almeida et al., 2009; Boroski et al., 2011; Leite et al., 2011), but studies on beet leaf are unprecedented.

\section{Materials and methods}

\subsection{Samples}

Leaves of beetroot organically produced in the municipality of Maringá, Paraná State $\left(23^{\circ} 25^{\prime}\right.$ south and $51^{\circ} 57^{\prime}$ west $)$, Brazil, were harvested 60,80 , and 100 days after planting although harvesting is commonly done after 80 days.

Harvest was performed at 60, 80, and 100 days between May and August 2010 (three harvest seasons). Different stages of maturation were investigated because the beetroots can be removed at 60 or 100 days. In natura beetroot leaves (NBL) were kept at $4{ }^{\circ} \mathrm{C}$ and analyzed up to $36 \mathrm{~h}$ after harvesting. Dehydrated beetroot leaves (DBL) were obtained by drying in natura leaves in an air-circulation oven (Quimis Model Q-314M292) with optimized air circulation (Visentainer et al., 2009), according to Almeida et al. (2009) The beetroot leaves were dried in order to increase their useful life.

\subsection{Proximate composition}

Moisture, ash, and crude protein contents were determined in accordance with AOAC - Association of Official Analytical Chemists (2000). Total lipids were extracted using the Bligh and Dyer method (Bligh \& Dyer, 1959). Total carbohydrates were estimated by difference, and the energetic value was calculated considering the following energy conversion factors: carbohydrate 4 Kcal.g ${ }^{-1}\left(17 \mathrm{KJ} \mathrm{g}^{-1}\right)$, protein $4 \mathrm{Kcal.g}{ }^{-1}\left(17 \mathrm{KJ} . \mathrm{g}^{-1}\right)$, and lipid $9 \mathrm{Kcal.g}^{-1}\left(37{\left.\mathrm{KJ} . \mathrm{g}^{-1}\right)}\right.$ (Brasil, 1998).

For mineral determination, the samples were digested in a muffle at $600{ }^{\circ} \mathrm{C}$ for $6-8 \mathrm{~h}$ until complete organic matter decomposition and were recovered with nitric acid solution (5\% v/v) (approximately $90^{\circ} \mathrm{C}$ ). K, Ca, Mg, Fe, Cu, Zn, Co, $\mathrm{Mn}$, and $\mathrm{Na}$ were quantified using a flame atomic absorption spectrophotometer Analytikjena novAA 300 (equipped with software winAAS) as mg of mineral per $\mathrm{kg}$ of sample using the technical parameters of calibration according to Table 1. All samples were analyzed in three replicates.

\subsection{Chromatographic analysis}

The fatty acid methyl esters (FAME) were prepared by methylation of the total lipids (TL), as described by the Hartman \& Lago method (Hartman \& Lago, 1973). Methyl esters was separated by gas chromatography using a Shimadzu 14-A (Kyoto, Japan) gas chromatograph equipped with a flame ionization detector (FID) and a fused silica capillary column CP-Select CB-FAME (100 m x $0.25 \mathrm{~mm}$ id., $0.25 \mu \mathrm{m}$ film thickness, Varian, USA). The sample splitting rate was 1:100, and the samples $(2 \mu \mathrm{L})$ were injected in triplicate. The operation parameters were as follows: detector temperature $230{ }^{\circ} \mathrm{C}$, injection port temperature $220^{\circ} \mathrm{C}$, and column temperature $150{ }^{\circ} \mathrm{C}$, which was programmed to increase up to $185^{\circ} \mathrm{C}$ at $2{ }^{\circ} \mathrm{C} \mathrm{min}$ min $^{-1}$ and next up to $225^{\circ} \mathrm{C}$ at $10^{\circ} \mathrm{C}$ min $^{-1}$ and held at this temperature for $20 \mathrm{~min}$ for a running time of around $42 \mathrm{~min}$. The peak areas were determined by the Workstation 5.0 (Varian) acquisition program. For the identification of fatty acids, retention times were compared with those of standard methyl esters (Sigma, USA).

Table 1. Calibration parameters for an atomic absorption spectrophotometer.

\begin{tabular}{ccccc}
\hline Element & Wavelength $(\mathrm{nm})$ & Spectral bandwidth $(\mathrm{nm})$ & Flame type & Current lamp $(\mathrm{mA})$ \\
\hline $\mathrm{Ca}$ & 239.9 & 0.2 & acetylene/nitrous oxide & 10 \\
$\mathrm{~K}$ & 404.4 & 0.5 & Acetylene & 5 \\
$\mathrm{Mg}$ & 202.6 & 1.0 & acetylene/nitrous oxide & 4 \\
$\mathrm{Fe}$ & 248.3 & 0.2 & Acetylene & 5 \\
$\mathrm{Cu}$ & 324.8 & 0.5 & acetylene/nitrous oxide & 4 \\
$\mathrm{Zn}$ & 213.9 & 1.0 & acetylene/nitrous oxide & 5 \\
$\mathrm{Co}$ & 240.7 & 0.2 & acetylene/nitrous oxide & 7 \\
$\mathrm{Mn}$ & 279.2 & 0.2 & acetylene/nitrous oxide & 5 \\
$\mathrm{Na}$ & 330.3 & 0.2 & Acetylene & 5 \\
\hline
\end{tabular}


Quantification (in mg fatty acid $\mathrm{g}^{-1}$ of total lipids) was performed against tricosanoic acid methyl ester as an internal standard (23:0), as described by Joseph \& Ackman (1992). Theoretical FID (flame ionization detector) correction factor values were used to obtain concentration values (Visentainer, 2012). Fatty acid contents were calculated in $\mathrm{mg}^{-\mathrm{g}^{-1}}$ of total lipids using Equation 1.

$\mathrm{FA}=\mathrm{A}_{\mathrm{x}} \times \mathrm{W}_{\text {is }} \times \mathrm{CF}_{\mathrm{x}} / \mathrm{A}_{\mathrm{is}} \times \mathrm{CF}_{\mathrm{AE}} \times \mathrm{W}_{\mathrm{A}}$

where FA is mg of fatty acids per $g$ of total lipids, $A_{X}$ is the peak area (fatty acids), $\mathrm{A}_{\mathrm{IS}}$ is the peak area of the internal standard (IS) methyl ester of tricosanoic acid (23:0), $\mathrm{W}_{\text {IS }}$ is the IS weight $\left(\mathrm{mg}\right.$ ) added to the sample (in $\mathrm{mg}$ ), $\mathrm{W}_{\mathrm{X}}$ is the sample weight (in $\mathrm{mg}), \mathrm{CF}_{\mathrm{X}}$ is the theoretical correction factor, and $\mathrm{CF}_{\mathrm{AE}}$ is the conversion factor necessary to express results as $\mathrm{mg}$ of fatty acids rather than as methyl esters. The results were converted from mg fatty acid per $\mathrm{g}$ of total lipid to mg fatty acid per $\mathrm{g}$ of leaves. All samples were analyzed in three replicates.

\subsection{Antioxidant activity}

Extract preparation: NBL and DBL were mixed with methanol in the ratio of 1:10 (w/v) under magnetic stirring for $5 \mathrm{~h}$ in the dark. After filtration, the methanolic extracts were concentrated under reduced pressure at $40^{\circ} \mathrm{C}$.

$D P P H$ assay: The antioxidant capacity of the leaf extracts was studied against DPPH free radical scavenging effect, according to El Massary et al. (2002).

Different aliquots of methanolic extract solution $(2.0 \mathrm{mg} /$ $\mathrm{mL}$ ) were mixed with $2.0 \mathrm{~mL}$ of DPPH methanolic solution $\left(4.70 \times 10^{-2} \mathrm{mg} \cdot \mathrm{mL}^{-1}\right)$. The mixture was thoroughly mixed on a vortex-mixer and kept in the dark for $30 \mathrm{~min}$. Next, absorbance was measured at $517 \mathrm{~nm}$ using a spectrophotometer (Cary Win UV 50, Varian) against a methanol blank without DPPH. The results were expressed as percent inhibition of the DPPH radical, which was calculated according to Equation 2, as follows.

\% Inhibition DPPH• $=\left(\mathrm{Abs}_{\mathrm{DPPH} \cdot}-\mathrm{Abs}_{\text {sample }}\right) /\left(\mathrm{Abs}_{\mathrm{DPPH} \cdot}\right) \times 100$

where $\mathrm{Abs}_{\mathrm{DPPH}}$ is the absorbance of the $\mathrm{DPPH}{ }^{\bullet}$ solution without extracts and $\mathrm{Abs}_{\text {sample }}$ is the absorbance of the sample solution.

The analyses were carried out in triplicate, and the extract concentration providing $50 \%$ inhibition of $\mathrm{DPPH}\left(\mathrm{IC}_{50}\right)$ was obtained by plotting the concentrations of the extract solutions versus percent inhibition. All samples were analyzed in three replicates.

Total phenolic compounds (TPC): The TPC were estimated according to the Folin-Ciocalteau method with some modifications for plant extracts (Kujala et al., 2000; Wu et al., 2005). An aliquot of $0.25-\mathrm{mL}$ of the extract methanol solution (2.50 mg. $\mathrm{mL}^{-1}$ ) was mixed with $0.25 \mathrm{~mL}$ of Folin-Ciocalteau reagent previously diluted with water $1: 1 \mathrm{v} / \mathrm{v}, 0.50 \mathrm{~mL}$ of a saturated sodium carbonate solution, and $4.0 \mathrm{~mL}$ of water. The mixture was left to rest at room temperature for $25 \mathrm{~min}$ and then centrifuged at $2000 \mathrm{rpm}$ for $10 \mathrm{~min}$. The supernatant absorbance was measured at $725 \mathrm{~nm}$ using a spectrophotometer (Cary Win UV 50, Varian). The results were expressed as milligrams of gallic acid equivalents per $\mathrm{g}$ of leaves (mg GAE.g $\left.{ }^{-1}\right)$. All samples were analyzed in three replicates.

\subsection{Statistical analysis}

Analysis of variance (ANOVA) was used to test the difference between means (stages of development), which were analyzed by the Tukey test at $95 \%(p<0.05)$ level of significance using the STATISTIC software version 7.0 (StatSoft, 2004).

\section{Results and discussion}

\subsection{Proximate composition}

Table 2 presents the proximate composition of in natura $(\mathrm{NBL})$ and dehydrated (DBL) leaves at different stages of maturation (60, 80, and 100 days). After dehydration, the leaf constituents were concentrated thus increasing the values of ashes, crude protein, total lipid, carbohydrate, and energy as compared to those of in natura leaves. According to Table 2, the moisture values of NBL and DBL were significantly different $(\mathrm{P}<0.05)$. NBL harvested at 60,80 , and 100 days lost 93, 90, and $88 \%$ water during drying, respectively. As for the ash contents, DBL had significant values $\left(\mathrm{g} . \mathrm{kg}^{-1}\right)$ ranging from $145.06 \pm 0.98$ (100 days) to $184.33 \pm 6.81$ (60 days). The crude protein contents of DBL ranged from $264.12 \pm 21.10 \mathrm{~g} \cdot \mathrm{kg}^{-1}$ (60 days) to $310.25 \pm 3.63 \mathrm{~g} \cdot \mathrm{kg}^{-1}$ (100 days); thus it can be considered a promising protein source for those who have limited access to animal protein. The ash and protein contents found in the DBL were higher than those found by Kinupp \& Barros (2008) in 52 vegetable species and 36 hydroponics. The ash and protein contents of DBL were greater than the values

Table 2. Proximate composition of in natura (NBL) and dehydrated (DBL) beetroot leaves at different stages of development.

\begin{tabular}{|c|c|c|c|c|c|c|}
\hline $\begin{array}{l}\text { Development } \\
\text { Stages (days) }\end{array}$ & $\begin{array}{c}\text { Moisture } \\
\left.\text { (g. Kg }{ }^{-1} \text { leaves }\right)\end{array}$ & $\begin{array}{c}\text { Ash } \\
\left.\text { (g.Kg }{ }^{-1} \text { leaves }\right)\end{array}$ & $\begin{array}{l}\text { Crude Protein } \\
\text { (g. } \mathrm{Kg}^{-1} \text { leaves) }\end{array}$ & $\begin{array}{c}\text { Total Lipids (g. } \mathrm{Kg}^{-1} \\
\text { leaves) }\end{array}$ & $\begin{array}{l}\text { Carbohydrate }^{\dagger} \\
\text { (g.Kg } \text { Kg leaves) }^{-1}\end{array}$ & $\begin{array}{c}\text { Energy } \\
\left({\left.\mathrm{Kcal} . \mathrm{kg}^{-1}\right)^{\star}}^{-}\right.\end{array}$ \\
\hline NBL 60 & $870.42^{\mathrm{a}} \pm 0.51$ & $22.71^{\mathrm{a}} \pm 0.06$ & $40.37^{\mathrm{a}} \pm 2.18$ & $12.95^{\mathrm{a}} \pm 1.89$ & $53.93^{\mathrm{a}} \pm 2.57$ & $474.35^{\mathrm{a}} \pm 5.72$ \\
\hline NBL 80 & $892.14^{\mathrm{b}} \pm 1.06$ & $17.58^{\mathrm{a}} \pm 0.03$ & $39.57^{\mathrm{a}} \pm 0.19$ & $9.22^{\mathrm{a}} \pm 0.47$ & $41.35^{\mathrm{a}} \pm 1.39$ & $397.58^{\mathrm{a}} \pm 1.77$ \\
\hline DBL 60 & $57.42^{\mathrm{d}} \pm 2.19$ & $184.33^{\mathrm{b}} \pm 6.81$ & $264.12^{\mathrm{b}} \pm 21.10$ & $86.42^{\mathrm{b}} \pm 5.21$ & $410.19^{\mathrm{b}} \pm 14.44$ & $3,350 \cdot 19^{\mathrm{b}} \pm 37.42$ \\
\hline DBL 80 & $85.08^{\mathrm{e}} \pm 0.73$ & $156.09^{c} \pm 0.61$ & $287.53^{b c} \pm 23.01$ & $105.63^{b c} \pm 9.07$ & $365.66^{c} \pm 14.33$ & $3,472.02^{c} \pm 43.16$ \\
\hline DBL 100 & $105.90^{f} \pm 1.58$ & $145.06^{\mathrm{d}} \pm 0.98$ & $310.25^{c} \pm 3.63$ & $127.32^{c} \pm 9.48$ & $307.21^{\mathrm{d}} \pm 8.35$ & $3,584.56^{\mathrm{d}} \pm 77.96$ \\
\hline
\end{tabular}

Results \pm standard deviation. NBL $=$ in natura beetroot leaves, $\mathrm{DBL}=$ Dehydrated beetroot leaves. ${ }^{\dagger}$ Values were calculated by difference. ${ }^{\star}$ Expressed in $\mathrm{Kcal}_{\mathrm{Kg}}{ }^{-1}$. Means followed by the same superscript letter in the same column are not significantly different $(\mathrm{p}<0.05)$. All chemical analyses were performed in triplicate. 
reported by Pereira et al. (2003) and Leite et al. (2011) for dehydrated carrot (Dacus carota L.) leaves. The carbohydrate content was higher in 60-day leaves and decreased during the developmental stages (from $53.93 \pm 2.57$ to $39.88 \pm 1.02 \mathrm{~g} \mathrm{~kg}^{-1}$ ). The carbohydrate contents of NBL were higher than the values reported by Ohse et al. (2012).

NBL showed low total lipid contents; the highest value was $12.95 \pm 1.89 \mathrm{mg} \cdot \mathrm{kg}^{-1}$ (60 days). However, in comparison to other vegetable leaves collected in South Africa (Odhav et al., 2007), for example, Amaranthus, Chenopodium, and Physalis, the chemical composition of NBL stands out for its amount of lipids. Drying increased the lipid content of the leaves by 85,91 , and $94 \%$ in NBL harvested at 60,80 , and 100 days, respectively. The highest carbohydrate contents were detected in DBL harvested at 60 days, and the energy values were higher for DBL harvested at 100 days.

Dehydrated leaves contained significant ash levels; nutritionally important macro- and micro minerals stood

Table 3. Minerals in dehydrated beetroot leaves (DBL) (mg.kg-1 dry leaves) at three different stages of development.

\begin{tabular}{cccc}
\hline & 60 days & 80 days & 100 days \\
\hline $\mathrm{K}$ & $13,367.64^{\mathrm{a}} \pm 735.17$ & $13,379.48^{\mathrm{a}} \pm 128.49$ & $20,784.90^{\mathrm{b}} \pm 898.70$ \\
$\mathrm{Ca}$ & $1,476.35^{\mathrm{a}} \pm 40.20$ & $1,568.07^{\mathrm{a}} \pm 60.31$ & $1,864.85^{\mathrm{b}} \pm 4.81$ \\
$\mathrm{Mg}$ & $1.83^{\mathrm{a}} \pm 0.10$ & $2.09^{\mathrm{b}} \pm 0.19$ & $1.79^{\mathrm{c}} \pm 0.03$ \\
$\mathrm{Fe}$ & $342.75^{\mathrm{a}} \pm 48.56$ & $187.30^{\mathrm{b}} \pm 33.92$ & $256.30^{\mathrm{ab}} \pm 29.49$ \\
$\mathrm{Cu}$ & $12.76^{\mathrm{a}} \pm 0.73$ & $12.23^{\mathrm{a}} \pm 0.20$ & $13.42^{\mathrm{a}} \pm 4.64$ \\
$\mathrm{Zn}$ & $11.63^{\mathrm{a}} \pm 0.44$ & $11.52^{\mathrm{a}} \pm 0.36$ & $13.31^{\mathrm{a}} \pm 1.99$ \\
$\mathrm{Co}$ & $1.29^{\mathrm{a}} \pm 0.27$ & $0.54^{\mathrm{b}} \pm 0.07$ & $0.10^{\mathrm{a}} \pm 0.01$ \\
$\mathrm{Mn}$ & $17.59^{\mathrm{a}} \pm 1.47$ & $15.49^{\mathrm{a}} \pm 8.97$ & $8.83^{\mathrm{b}} \pm 3.66$ \\
$\mathrm{Na}$ & $7,907.01^{\mathrm{a}} \pm 245.41$ & $5,534.37^{\mathrm{b}} \pm 627.70$ & $4,724.63^{\mathrm{b}} \pm 417.32$ \\
\hline
\end{tabular}

Results \pm standard deviation. DBL $=$ Dehydrated beetroot leaves. Means followed by the same superscript letter in the same column are not significantly different $(\mathrm{p}<0.05)$. All chemical analyses were performed in triplicate. out. The macro- and micro mineral composition of DBL are presented in Table 3.

According to the Brazilian sanitary surveillance agency (Agência Nacional de Vigilância Sanitária, 2004), the recommended daily intake (RDI) of $\mathrm{Fe}$ and $\mathrm{Cu}$ for adults is 14 and $0.9 \mathrm{mg} / \mathrm{d}$, respectively and the consumption of $70 \mathrm{~g}$ (about 2 cups) of DBL provides the recommended amounts of these micro minerals. The Fe content of DBL varied from $187.30 \pm$ 33.92 to $342.75 \pm 48.56 \mathrm{mg} \cdot \mathrm{kg}^{-1}$ of leaves, and the largest amount was observed at 60 days. The best sources of Fe are red meat, vegetables, and grains (Pereira et al., 2003).

In the present study, as previously mentioned, good levels of Fe were found in the beetroot leaves. The beetroot leaves have more Fe than other vegetable leaves such as Senna occidentalis (110 mg.kg-1 ${ }^{-1}$, Chenopodium album (130 mg. $\mathrm{kg}^{-1}$ ), and Justicia flava (160 mg. $\mathrm{kg}^{-1}$ ) (Odhav et al., 2007).

Beetroot leaves contain high amount of $\mathrm{Cu}$, similar to the levels reported for watercress and rocket (Ekholm et al., 2007). High $\mathrm{K}$ contents were determined, as expected for vegetables and fruits since $\mathrm{K}^{+}$is necessary for the metabolism of carbohydrates and proteins ${ }^{3}$ and the RDI for potassium varied from 1,950 to $5,900 \mathrm{mg} / \mathrm{d}$ (Brasil, 1998). The consumption of $145 \mathrm{~g}$ (about 4 cups) of DBL provides the recommended amounts of potassium.

\subsection{Fatty acid composition (Fatty acid content)}

The presence of saturated (SFA), monounsaturated (MUFA), and polyunsaturated (PUFA) fatty acids in the leaves of beetroot was investigated (Table 4). Among the SFA, pentadecilic (15:0), palmitic (16:0), and stearic (18:0) acids were identified. The MUFA identified were pentadecenoic (15:1n-9), palmitoleic (16:1n-7), oleic (18:1 n-9), and vaccenic acids (18:1n-7). The commonly PUFA present in the lipid fraction of leaves are linoleic (LA, 18:2n-6) and alpha-linolenic (LNA, 18:3n-3) acids, which belong to the $\omega-6$ and $\omega-3$ families, respectively.

Table 4. Concentration of fatty acids (mg. $\mathrm{g}^{-1}$ leaves) in in natura (NBL) and dehydrated (DBL) beetroot leaves at the different stages of development.

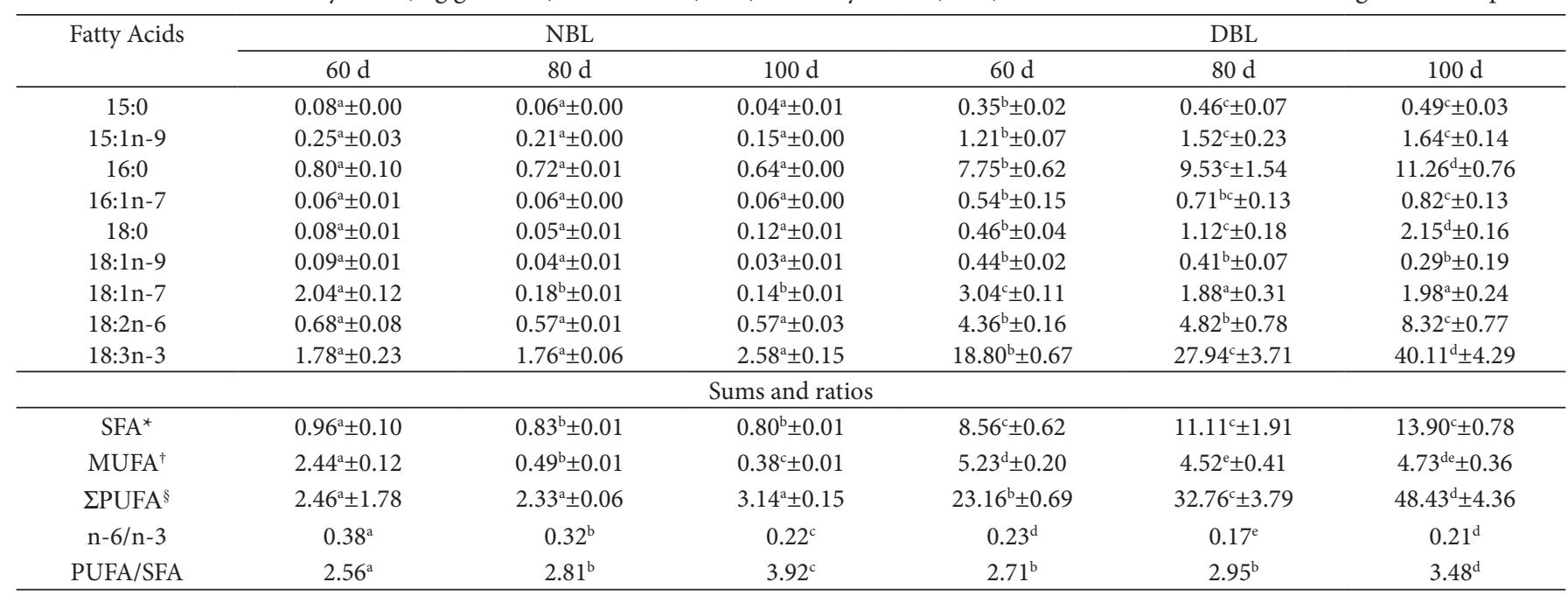

Values are mean \pm standard deviation of triplicate analyses. NBL $=$ in natura beetroot leaves; DBL $=$ dehydrated beetroot leaves. ${ }^{*}$ SFA: Saturated fatty acid; ${ }^{\dagger} \mathrm{MUFA}$ : Monounsaturated fatty acid; ${ }^{\circledR}$ PUFA: Polyunsaturated fatty acid. Different letters in the same line indicate significant differences $(\mathrm{P}<0.05)$ by the Tukey test. 
Identifying the fatty acids present in beetroot leaves, especially those of $\omega-6$ and $\omega-3$ families, is very important because these acids occur in larger amounts in dark green leaves than in the leaves of other vegetables due to the lipids contained in the chloroplasts (Martin et al., 2006).

LNA was the fatty acid found in the highest amount in the beetroot leaves at all the stages of development studied. This fatty acid is an important component of chloroplast membrane lipids (Simopoulos, 2002). During the vegetal development, the highest concentration of LNA was found in the 100-day leaves, with $2.58 \pm 0.15 \mathrm{mg} . \mathrm{g}^{-1}$ in NBL and $40.11 \pm 4.29 \mathrm{mg} . \mathrm{g}^{-1}$ in DBL.

The $n-6 / n-3$ ratio has changed in the last years. The current estimates for western societies suggest a n-6/n-3 ratio of 10-20:1 instead of 1:1 (Simopoulos, 2011); thus, since it is necessary to reduce this ratio, beetroot leaves rich in $\mathrm{n}-3$ can be included in the western diets. The $n-6 / n-3$ ratios found in the present study varied from 0.17 to 0.38 ; therefore beetroot leaves can help maintain a healthy diet. Although the total lipid contents are low, the consumption of these leaves increase the intake of essential fatty acids such as LNA ( $\omega-3)$.

The fatty acid founds in the beetroot leaves can be compared to those of carrot leaves (Leite et al., 2011) since both have large amounts of LNA; however, beetroot leaves have a 4.7 times higher content of these acids; 100 -day dehydrated carrot leaves had $856.55 \mathrm{mg} .100 \mathrm{~g}^{-1}$ leaves of and dehydrated beetroot leaves had 4,011.02 mg. $100 \mathrm{~g}^{-1}$. Beetroot leaves showed low $\mathrm{n}-6 / \mathrm{n}-3$ ratio, on average of 0.48 of carrot leaves (Leite et al., 2011) and 0.20 of beetroot leaves. Analyzing the PUFA/SFA ratio, it was verified that the values obtained for all samples were higher than the minimum value recommended, 0.45 (Her Majesty's Stationery Office, 1994).

In previous studies, dehydrated carrot leaves that had significant amounts of essential fatty acids such as $\omega-3$ were used in the formulation of pasta (Boroski et al., 2011), and therefore, this enriched formulation had high levels of LNA and low $\mathrm{n} 6 / \mathrm{n}-3$ ratio.

Therefore, beetroot leaves can also be used in food formulations to improve its LNA levels.

\subsection{Antioxidant activity by DPPH radical}

Antioxidants have been largely studied in the food and agriculture fields, and the DPPH assay has been widely used since it is a simple and highly sensitive method (Moon \& Shibamoto, 2009). Beetroots have been studied for their content of betalains, compounds that have antioxidant properties (Wootton-Beard \& Ryan, 2011); however, beetroot leaves can also have antioxidant properties.

NBL had better antioxidant activity in the DPPH assay than DBL (Figure 1). A smaller amount of extract was necessary to inhibit $50 \%$ of the free radical $\left(\mathrm{IC}_{50}\right), 89.52$ and $125.24 \mu \mathrm{g} \cdot \mathrm{mL}^{-1}$ in NBL at 60 and 80 days, respectively, since the presence of water increases permeability of cell tissue, and thus it enables better mass transfer by molecular diffusion and the recovery of water soluble bioactive compounds (Jayaprakasha et al., 2001;

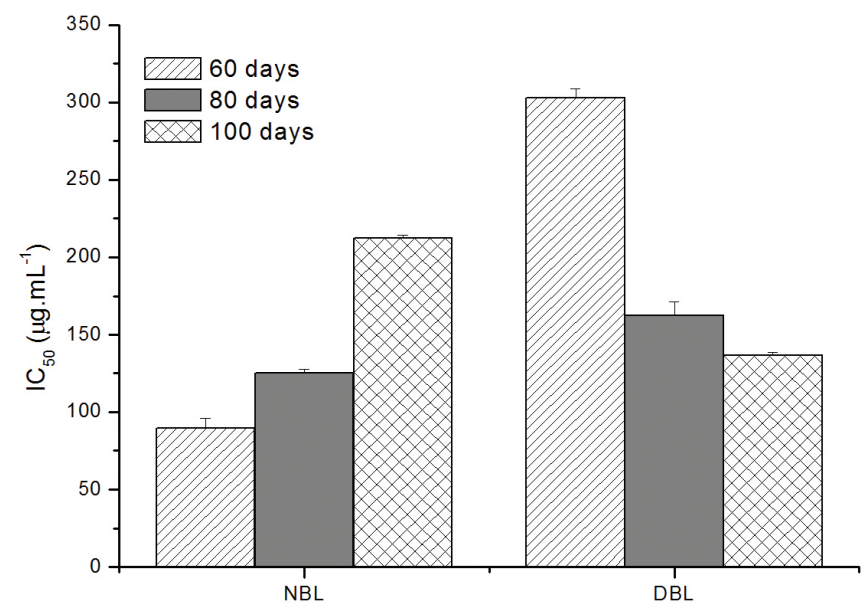

Figure 1. $\mathrm{IC}_{50}$ values (concentration of methanolic extract ( $\left.\mu \mathrm{g} \cdot \mathrm{mL}^{-1}\right)$ ) necessary to inhibit $50 \%$ of the DPPH radical for NBL and DBL harvested at different stages of development.

Cheng et al., 2012). The DPPH results obtained are similar to those of organic and conventional vegetables (Arbos et al., 2010).

Assays of antioxidant activity by DPPH in leaves $\left(\mathrm{IC}_{50}\right.$, $\mu \mathrm{g} \cdot \mathrm{ml}^{-1}$ ) are available in the literature, but there is no standardization in terms of the extraction of compounds responsible for such antioxidant activity; nonetheless, there are studies on leaves and plants using different extraction solvents such as water (Tung et al., 2009), ethanol (Argoti et al., 2011) and acetone:water (Liu et al., 2007).

\subsection{Total Phenolic Compounds (TPC)}

Different amounts of phenolic compounds and levels of antioxidant activity were observed for the different stages of development. According to Bulbovas et al. (2005), these variations are due to seasonal factors. Extreme environmental factors led to an increase in the concentration of reactive oxygen species, and consequently, in the antioxidant activity.

In plants, compounds or classes of phenolic compounds such as phenolic acids are responsible for antioxidant activity (Angelo \& Jorge, 2007; Lako, 2007) and are present in vegetable leaves (Moon \& Shibamoto, 2009; Fernandes et al., 2007). According to Maisuthisakula (2008), in some species of plants, the antioxidant activity is correlated with their phenolic compounds, while in others, it is not.

The total phenolic contents in dried beetroot leaves (DBL) was higher than those found in in natura beetroot leaves (NBL), when the results were expressed as fresh weight (FW) (Figure 2a) due to the moisture content in this leaves (Table 2); the 100- day DBL showed larger amounts of phenolic compounds. However, when calculating the total phenolic content in dry weight (DW), it was observed that the values were higher in NBL than in DBL (Figure 2b). The phenolic compounds may be responsible for the antioxidant activity; however, in the present study, this was not observed. In other studies on food matrices the relationship between phenolic compounds and antioxidant activity has been observed, as reported by Michiels et al. (2012). 


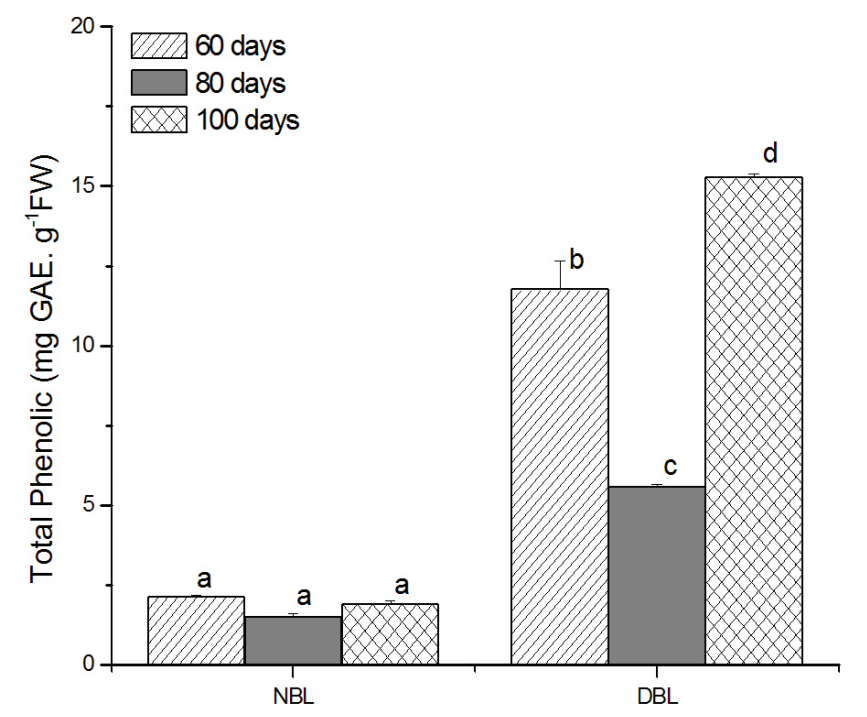

(a)

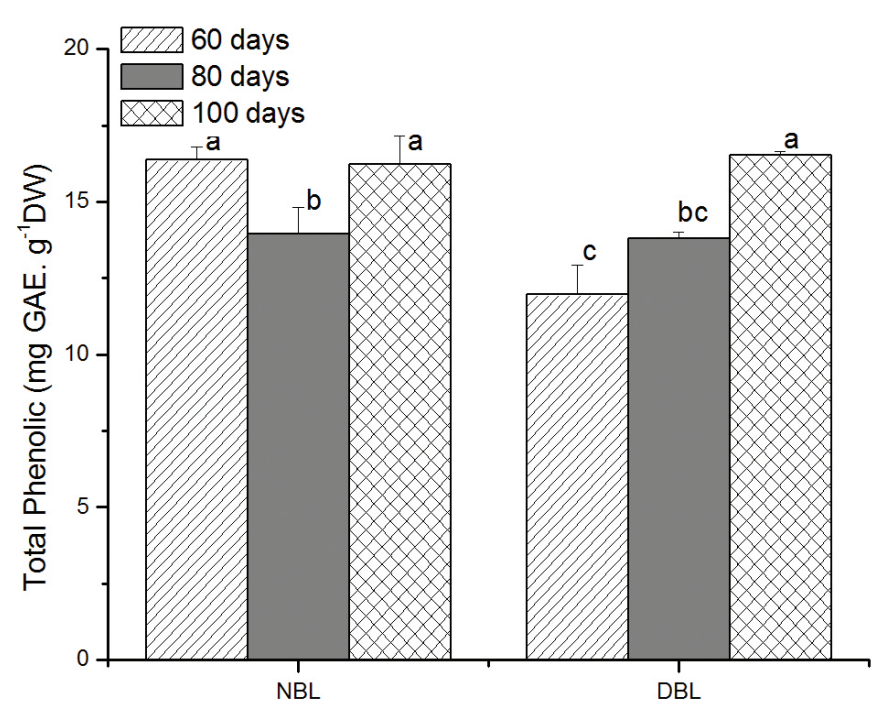

(b)

Figure 2. Phenolic compounds expressed as quantity of gallic acid equivalent (mg GAE. $\mathrm{g}^{-1}$ ) of the methanolic extracts of NBL and DBL as (a) fresh weight (FW) and (b) dry weight (DW). Same superscript letters in the same rectangular bars in the bar chart indicate no significant difference $(\mathrm{p}<0.05)$.

\section{Conclusion}

The present study showed that beetroot leaves are an excellent source of omega-3, in addition to having significant antioxidant activity and amounts of total phenolic compounds, macro- and micro minerals. The chemical constituents in the leaves changed during the development stages, and the greatest amount of omega-3 and 6 and the amount of total phenolic compounds and some minerals were found in the 100-day leaves. Protein and lipids contents were the highest in the 60day leaves; thus, the leaves can be consumed in more than one stage of development. Therefore, it can be said that in natura and dehydrated beetroot leaves can be used in the preparation of broths, meals and/or added to other foods, and that the dehydrated leaves have the greatest nutritional value.

\section{Acknowledgements}

The authors are grateful for the financial support provided by Conselho Nacional de Desenvolvimento Científico e Tecnológico (CNPq).

\section{References}

Abdel-Hameed, E. (2009). Total phenolic contents and free radical scavenging activity of certain Egyptian Ficus species leaf samples. Food Chemistry, 114(4), 271-1277. http://dx.doi.org/10.1016/j. foodchem.2008.11.005

Agencia Nacional de Vigilância Sanitária - Anvisa. (2004). Regulamento Técnico sobre a Ingestão Diária Recomendada (IDR) de Proteína, Vitaminas e Minerais (Decreto no 3.029, de 16 de Abril de 1999). Diário Oficial da República Federativa do Brasil.

Almeida, V. V., Bonafé, E. G., Muniz, E. C., Matsushita, M., Souza, N. E., \& Visentainer, J. V. (2009). Optimization of the carrot leaf dehydration aiming at the preservation of Omega-3 fatty acids.
Química Nova, 32(5), 1334-1337. http://dx.doi.org/10.1590/S010040422009000500042

Amaral, A. S., Anghinoni, I., \& Deschamps, F. C. (2004). Resíduo de plantas de cobertura e mobilidade dos produtos da dissolução do calcário aplicado na superfície do solo. Revista Brasileira de Ciência do Solo, 28(1), 115-123. http://dx.doi.org/10.1590/S010006832004000100012

Angelo, P. M., \& Jorge, N. (2007). Compostos fenólicos em alimentos - Uma breve revisão. Revista do Instituto Adolfo Lutz, 66(1), 232-240.

Arbos, K. A., Freitas, R. J. S, Stertz, S. C., \& Dornas, M. F. (2010). Atividade antioxidante e teor de fenólicos totais em hortaliças orgânicas e convencionais. Food Science and Technology (Campinas), 30(2), 501-506.

Argoti, J. C., Salido, S., Linares-Palomino, P. J., Ramírez, B., Insuasty, B., \& Altarejos, J. (2011). Antioxidant activity and free radicalscavenging capacity of a selection of wild-growing Colombian plants. Journal of the Science of Food and Agriculture, 91(13), 2399-2406. http:// dx.doi.org/10.1002/jsfa.4476

Association of Official Analytical Chemists - AOAC. (2000). Official Methods of Analysis of AOAC International (17th ed.). Gaithersburg: Association of Analytical Communities.

Bligh, F. G., \& Dyer, W. J. (1959). A rapid method of total lipid extraction and purification. Canadian Journal of Biochemistry and Physiology, 37(8), 911-917. http://dx.doi.org/10.1139/059-099

Boroski, M., Aguiar, A. C., Boeing, J. S., Rotta, E. M., Wibby, C. L., Bonafé, E. G., Souza, N. E., \& Visentainer, J. V. (2011). Enhancement of pasta antioxidant activity with oregano and carrot leaf. Food Chemistry, 125(2), 696-700. http://dx.doi.org/10.1016/j. foodchem.2010.09.068

Brasil. (1998). A Secretária de Vigilância Sanitária do MS adota a Ingestão Diária Recomendada (IDR) para vitaminas, minerais e proteínas (Portaria n.33 SVS/MS, de 13 de janeiro de 1998). Diário Oficial da República Federativa do Brasil. 
Brasil. Ministério da Saúde. Secretaria de Vigilância Sanitária. (1998). Aprova o regulamento técnico referente à rotulagem nutricional de alimentos embalados (Portaria n. 41 de 14 de janeiro de 1998). Diário Oficial da República Federativa do Brasil.

Bulbovas, P., Rinaldi, M. C. S., Delitti, W. B. C., \& Domingos, M. (2005). Variação sazonal em antioxidantes em folhas de plantas jovens de Caesalpinia echinata Lam. (pau-brasil). Revista Brasileira de Botanica, 28(4), 687-696.

Carvalho, M. A., Zanini, S. F., Timpani, V. D., \& Leal, F. B. (2002). Utilização da parte aérea da mandioca, Manihot Esculenta Crantz, na alimentação animal. Scientia Vila Velha (ES), 3(1), 57-67.

Celli, G. B., Pereira-Netto, A. B., \& Beta, T. (2011). Comparative analysis of total phenolic content, antioxidant activity, and flavonoids profile of fruits from two varieties of Brazilian cherry (Eugenia uniflora L.) throughout the fruit developmental stages. Food Research International, 44(8), 2442-2451. http://dx.doi.org/10.1016/j. foodres.2010.12.036

Cheng, V. J., Bekhit, A. E. A., McConnell, M., Mros, S., \& Zhao, J. (2012). Effect of extraction solvent, waste fraction and grape variety on the antimicrobial and antioxidant activies of extracts from wine residue from cool climate. Food Chemistry, 134(1), 474-482. http://dx.doi. org/10.1016/j.foodchem.2012.02.103

Chun, S. S., Vatattem, D. A., Lin, Y. T., \& Shetty, K. (2005). Phenolic antioxidants from clonal oregano (Origanum vulgare) with antimicrobial activity against Helicobacter pylori. Process Biochemistry, 40(2), 809-816. http://dx.doi.org/10.1016/j. procbio.2004.02.018

Connor, W. E. (2000). Importance of n-3 fatty acid in health and disease. American Journal of Clinical Nutrition, 71(1), 171S-175S.

Ekholm, P., Reinivuo, H., Mattila, P., Pakkala, H., Koponen, J., Happonen, A., Hellström, J., \& Ovaskainen, M. L. (2007). Changes in the mineral and trace element contents of cereal, fruits and vegetables in Finland. Journal of Food Composition and Analysis, 20(6), 487-495. http://dx.doi.org/10.1016/j.jfca.2007.02.007

El-Massary, K. F. E., El-Ghorab, A. H., \& Farouk, A. (2002). Antioxidant activity and volatile components of Egyptian Artemisia judaica $L$. Food Chemistry, 79(3), 331-336. http://dx.doi.org/10.1016/S03088146(02)00164-4

Fernandes, F., Valentão, P., Sousa, C., Pereira, J. Á., Seabra, R. M., \& Andrade, P. B. (2007). Chemical and antioxidative assessment of dietary turnip (Brassica rapa var. rapa L.). Food Chemistry, 105(3), 1003-1010. http://dx.doi.org/10.1016/j.foodchem.2007.04.063

Hartman, L., \& Lago, R. C. A. (1973). Rapid preparation of fatty acid methyl esters from lipids. Laboratory Practice, 22, 475-476.

Her Majesty's Stationery Office - HMSO. (1994). Nutritional aspects of cardiovascular disease. Report on health and social subjects no. 46. London: Department of Health.

Institute of Medicine of the National Academies. (2002). Dietary Reference Intakes for energy, carbohydrate, fiber, fat, fatty acids, cholesterol, protein and amino acids (pp. 422-542). Washington: National Academies Press.

Jayaprakasha, G. K., Singh, R. P., \& Sakariah, K. K. (2001). Antioxidant activity of grape seed (Vitis vinifera) extracts on peroxidation models in vitro. Food Chemistry, 73(3), 285-290. http://dx.doi.org/10.1016/ S0308-8146(00)00298-3

Joseph, J. D., \& Ackman, R. G. (1992). Capillary column gas chromatography method for analysis of encapsulated fish oil and fish oil ethyl esters: collaborative study. Journal of AOAC International, 75(3), 488-506.
Kabat, G. C., Park, Y., Hollenbeck, A. R., Schatzkin, A., \& Rohan, T. E. (2010). Intake of fruits and vegetables, and risk of endometrial cancer in the NIH-AARP Diet and Health Study. Cancer Epidemiology, 34(5), 568-573. http://dx.doi.org/10.1016/j.canep.2010.06.005

Kawashima, L. M., \& Soares, L. M. V. (2003). Mineral profile of raw and cooked leafy vegetables consumed in Southern Brazil. Journal of Food Composition and Analysis, 16(5), 605-611. http://dx.doi. org/10.1016/S0889-1575(03)00057-7

Kinupp, V. F., \& Barros, I. B. I. (2008). Teores de proteína e minerais de espécies nativas, potenciais hortaliças e frutas. Food Science and Technology (Campinas), 28(4), 846-857.

Kujala, T. S., Loponen, J. M., Klika, K. D., \& Pihlaja, K. (2000). Phenolics and Betacyanins in Red Beetrood (Beta Vulgaris) Root: Distribution and Effect of Cold Storage on the Content of Total Phenolics and Three Individual Compounds. Journal of Agricultural and Food Chemistry, 48(11), 5338-5342. http://dx.doi.org/10.1021/jf000523q

Lako, J., Trenerry, V. C., Wahlqvist, M., Wattanapenpaiboon, N., Sotheeswaran, S., \& Premier, R. (2007). Phytochemical flavonols, carotenoids and the antioxidant properties of a wide selection of Fijian fruit, vegetables and other readily available foods. Food Chemistry, 101(4), 1727-1741. http://dx.doi.org/10.1016/j. foodchem.2006.01.031

Leite, C. W., Boroski, M., Boeing, J. S., Aguiar, A. C., França, P. B., Souza, N. E., \& Visentainer, J. (2011). Chemical characterization of leaves of organically grown carrot (Dacus carota L.) in various stages of development for use as food. Food Science and Technology (Campinas), 31(3), 735-738.

Liu, X., Ardo, S., Bunning, M., Parry, J., Zhou, K., Stushnoff, C., Stoniker, F., Yu, L., \& Kendall, P. (2007). Total phenolic content and DPPH radical scavenging activity of lettuce (Lactuca sativa L.) grown in Colorado. LWT - Food Science and Technology, 40(3), 552-557. http://dx.doi.org/10.1016/j.lwt.2005.09.007

Maisuthisakula, P., Pasukb, S., \& Ritthiruangdejc, P. (2008). Relationship between antioxidant properties and chemical composition of some Thai plants. Journal of Food Composition and Analysis, 21(3), 229240. http://dx.doi.org/10.1016/j.jfca.2007.11.005

Martin, C. A., Almeida, V. V., Ruiz, M. R., Visentainer, J. E. L., Matshushita, M., De Souza, N. E., \& Visentainer, J. V. (2006). Ácidos graxos poliinsaturados ômega-3 e ômega-6: importância e ocorrência em alimentos. Revista de Nutrição, 19(6), 761-770. http:// dx.doi.org/10.1590/S1415-52732006000600011

Mello, D. F., Franzolini, R., Fernandes, L. B., Franco, A. V. M., \& Alves, T. C. (2008). Avaliação do resíduo de nabo forrageiro extraído da produção de biodiesel como suplemento para bovinos de corte em pastagens. Revista Brasileira de Saúde e Produção Animal, 9(1), 45-56.

Michiels, J. A., Kevers, C., Pincemail, J., \& Defraigne, J. O. (2012). Extraction conditions can greatly influence antioxidant capacity assays in plant food matrices. Food Chemistry, 130:986-993. http:// dx.doi.org/10.1016/j.foodchem.2011.07.117

Moon, J.-K., \& Shibamoto, T. (2009). Antioxidant assays for plant and food components. Journal of Agricultural and Food Chemistry, 57(5), 1655-1666. http://dx.doi.org/10.1021/jf803537k

Msilini, N., Oueslati, S., Amdouni, T., Chebbi, M., Ksouri, R., Lachaal, M., \& Ouerghi, Z. (2013). Variability of phenolic content and antioxidant activity of two lettuce varieties under Fe deficiency. Journal of the Science of Food and Agriculture, 93(8), 2016-2021. http://dx.doi.org/10.1002/jsfa.6008

Odhav, B., Beekrum, S., Akula, U., \& Baijinath, H. (2007). Preliminary assessment of nutritional value of traditional leafy vegetables in KwaZulu-Natal, South Africa. Journal of Food Composition 
and Analysis, 20(5), 430-435. http://dx.doi.org/10.1016/j. jfca.2006.04.015

Ohse, S., Carvalho, S. M., Rezende, B. L. A., De Oliveira, J. B., Manfron, P. A., \& Dourado Neto, D. (2012). Produção e composição química de hortaliças folhosas em hidroponia. Bioscience Journal, 28(2), 155-163.

Oliveira, I., Baptista, P., Malheiro, R., Casal, S., Bento, A., \& Pereira, J. A. (2011). Influence of strawberry tree (Arbutus unedo L.) fruit ripening stage on chemical composition and antioxidant activity. Food Research International, 44(5), 1401-1407. http://dx.doi. org/10.1016/j.foodres.2011.02.009

Padilha, P. C., \& Pinheiro, R. L. (2004). O papel dos alimentos funcionais na prevenção e controle do Câncer de Mama. Revista Brasileira de Cancerologia, 50(3), 251-260.

Pawlowska, A. M., De Leo, M., \& Braca, A. (2006). Phenolics of Arbutus unedo L. (Ericaceae) fruits: Identification of anthocyanins and gallic acid derivatives. Journal of Agricultural and Food Chemistry, 54(26), 10234-10238. http://dx.doi.org/10.1021/jf062230o

Peiretti, P. G., Gai, F., \& Tassone, S. (2013). Fatty acid profile and nutritive value of quinoa (Chenopodium quinoa Willd.) seeds and plants at different growth stages. Animal Feed Science and Technology, 183(1), 56-61. http://dx.doi.org/10.1016/j.anifeedsci.2013.04.012

Pereira, G. I. S., Pereira, R. G. F. A., Marcelos, M. F. P., \& Morais, A. R. (2003). Avaliação Química da folha de cenoura visando ao seu aproveitamento na alimentação humana. Ciência e Agrotecnologia, 27(4), 852-857. http://dx.doi.org/10.1590/S141370542003000400017

Silva, J. L., Gomes, S. D., Coelho, S. R. M., Evarini, J., Priscila, F., Cereda, M. P., \& Lucas, S. D. (2012). Obtenção de concentrado protéico de folhas e parte aérea da mandioca (Manihot esculenta Crantz). Semina: Ciências Agrárias, 33(6), 2279-2288. http://dx.doi. org/10.5433/1679-0359.2012v33n6p2279

Simopoulos, A. P. (2002). The importance of the ratio of omega-6/ omega-3 essential fatty acids. Biomedicine \& Pharmacotherapy, 56(8), 365-379. http://dx.doi.org/10.1016/S0753-3322(02)00253-6
Simopoulos, A. P. (2011). Evolutionary Aspects of Diet: The Omega-6/ Omega-3 Ratio and the Brain. Molecular Neurobiology, 44(2), 203215. http://dx.doi.org/10.1007/s12035-010-8162-0

StatSoft (2004). Statistica 7.0 Software. Tucksa: Statsoft.

Telci, I., Demirtas, I., \& Sahin, A. (2009). Variation in plant properties and essential oil composition of sweet fennel (Foeniculum vulgare Mill.) fruits during stages of maturity. Industrial Crops and Products, 30(1), 126-130. http://dx.doi.org/10.1016/j.indcrop.2009.02.010

Tung, Y. T., Wu, J. H., Hsieh, C. Y., Chen, P. S., \& Chang, S. T. (2009). Free radical-scavenging phytochemicals of hot water extracts of Acacia confuse leaves detected by an on-line screening method. Food Chemistry, 115, 1019-1024. http://dx.doi.org/10.1016/j. foodchem.2009.01.026

Vilhena, M. O., \& Silva, M. C. (2007). Aproveitamento integral de alimentos orgânicos: arte culinária verde. In II Jornada Nacional da Produção Científica em Educação Profissional e Tecnológica, São Luís.

Visentainer, J. V. (2012). Aspectos Analíticos da resposta do detector de ionização em chama para ésteres de ácidos graxos em biodiesel e alimentos. Química Nova, 35(2), 274-279. http://dx.doi.org/10.1590/ S0100-40422012000200008

Visentainer, J., Makoto, M., Souza, N. E., Aguiar, A. C., Bonafé, E. G., \& Almeida, V. V. (2009). Farinha de Folha de Cenoura. Instituto Nacional da Propriedade Industrial - INPI, PI n. 0901589-2.

Wootton-Beard, P. C., \& Ryan, L. (2011). A beetroot juice shot is a significant and convenient source of bioaccessible antioxidants. Journal of Functional Foods, 3(4), 329-334. http://dx.doi. org/10.1016/j.jff.2011.05.007

Wu, Y.-H., Tung, Y.-T., Wang, S.-Y., Shyur, L.-F., Kuo, Y.-H., \& Chang, S.-T. (2005). Phenolic Antioxidants from the Heartwood of Acacia confusa. Journal of Agricultural and Food Chemistry, 53(15), 59175921. http://dx.doi.org/10.1021/jf050550m

Zheng, W., \& Wang, S. Y. (2001). Antioxidant Activity and Phenolic Compounds in Selected Herbs. Journal of Agricultural and Food Chemistry, 49(11), 5165-5170. http://dx.doi.org/10.1021/jf010697n 